\title{
ПРО ДИСТАНЦІЙНУ ФОРМУ ДІЯЛЬНОСТІ ІНСТИТУТУ ОБДАРОВАНОЇ ДИТИНИ НАПН УКРАЇНИ В УМОВАХ ПАНДЕМІї COVID-19
}

https://doi.org/10.37472/2707-305X-2020-2-1-7-6

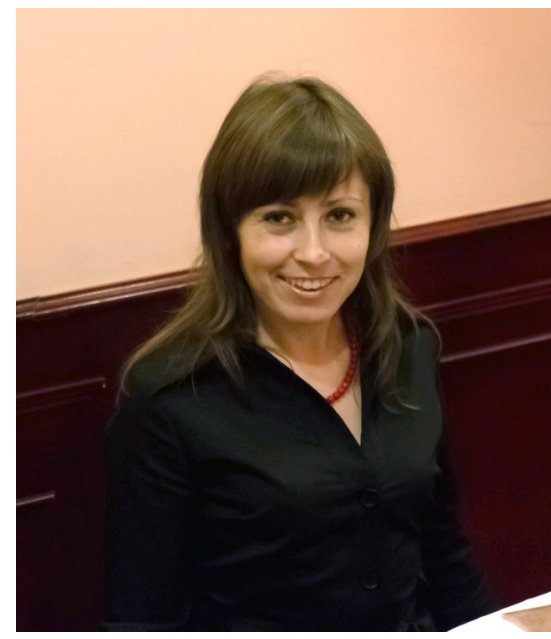

МАЛИНОШЕВСЬКА

Альона Василівна

кандидат педагогічних наук,

заступник директора з

наукової роботи Iнституту

обдарованої дитини

Національної академіі

педагогічних наук України,

м. Київ, Україна

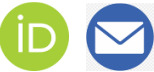

Анотація. У статmі розкрито основні напрями онлайн-діяльності Інституту обдарованої дитини НАПН України в умовах карантину, який запроваджено з метою протидії поширенню коронавірусної інфекційної хвороби COVID-19. Зазначено, що Інститут обдарованої дитини НАПН України має значний досвід дистаниійної комунікації та дистанційного науково-методичного супроводу розвитку обдарувань у дітей і молоді. Вже не один рік функціонує Всеукраїнський освітній інтернет-портал "Острів знань», який було створено науковими працівниками Інституту. Матеріали порталу призначені допомогти працівникам закладів освіти в організації дистанційного навчання, спрямовані на розвиток пізнавальних інтересів учнів, їхніх інтелектуальних і творчих здібностей. Вчені Інституту розробили онлайн-ресурс для діагностики рівня здібностей, професійних інтересів і схильностей учнів. Пандемія COVID-19 спонукала до інтенсивного пошуку нових моделей взаємодії у межах науково-методичного супроводу освіти обдарованих дітей. У період протиепідемічних заходів, запроваджених урядом України, працівники Інституту посилили свою присутність на низці цифрових платформ, здійснюючи онлайн-консультування учителів щодо проблем навчання обдарованих учнів. Окремим напрямом наукової діяльності стало проведення вебінарів, де висвітлюються новітні тренди освіти обдарованої дитини.

Ключові слова: Інститут обдарованої дитини НАПН України; Всеукраїнський освітній інтернет-портал "Острів знань»; онлайнресурс для діагностики рівня здібностей; освітньо-творчий проєкт; вебінар.

Пандемія коронавірусу стала причиною переходу на дистанційну форму навчання. Зрозуміло, що така ситуація спричинила чимало складнощів і водночас стала поштовхом до саморозвитку значної частини суспільства. Учителі, учні, а також батьки були вимушені швидко освоювати й оперативно застосовувати спеціалізовані програмні продукти для онлайн-навчання. Особливо ускладнився освітній процес для вчителів, яким необхідно враховувати особливості передачі та сприймання інформації через онлайн-форми, трансформувати зміст навчального матеріалу до оптимальних форм онлайн-навчання тощо. Закономірно, що швидкій переорієнтації вчителя відповідно до нових освітніх реалій сприяють уже наявні науково-методичні розробки супроводу освітнього процесу, підготовлені фахівцями Національної академії педагогічних наук України.

Інститут обдарованої дитини НАПН України має значний досвід використання інструментів дистанційного навчання і професійної дистанційної комунікації. Вчені Інституту створили Всеукраїнський освітній інтернет-портал «Острів знань» та постійно здійснюють 


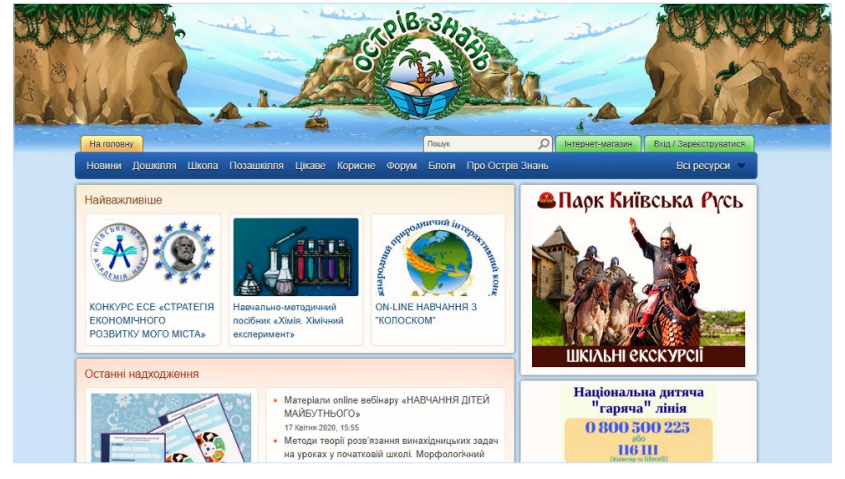

його науково-методичне забезпечення. Матеріали порталу спрямовані на надання допомоги працівникам закладів освіти в організації дистанційного навчання, сприяння розвитку пізнавальних інтересів учнів, їхніх інтелектуальних і творчих здібностей. Додатково на порталі оприлюднено матеріали щодо соціалізації, самореалізації, професійного самовизначення, стимулювання особистісного саморозвитку, збереження психологічного та фізичного здоров'я учнів.

Специфіка роботи з сучасними учнями передбачає застосування особистісно-орієнтованого підходу до кожного учня, неперервний процес індивідуального консультування, а також формування індивідуальної освітньої траєкторії. Саме для забезпечення конструювання індивідуальної освітньої траєкторії кожного учня Інститутом було розроблено онлайн-ресурс для діагностики рівня здібностей, професійних інтересів, схильностей учнів, особистісних характеристик. Кожен користувач (за умови реєстрації) має можливість пройти психологічну діагностику в онлайнрежимі та отримати результати тестування та відповідні рекомендації.

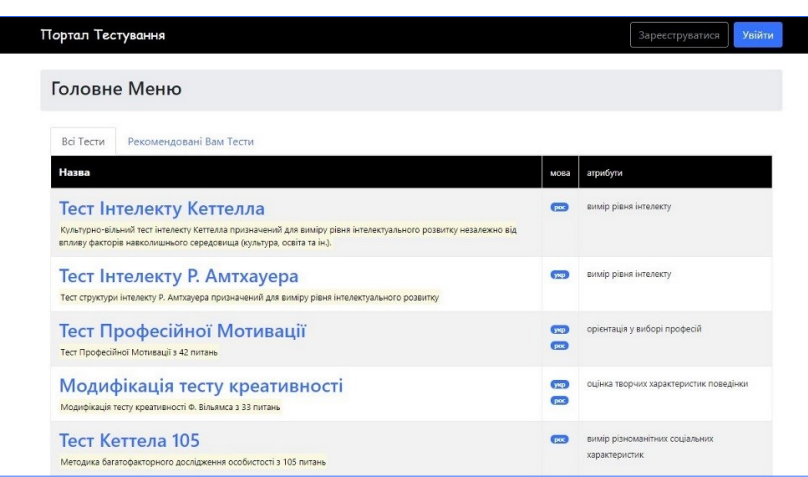

Інститут обдарованої дитини НАПН України спільно з Малою академією наук України здійснює науково-методичне забезпечення діяльності віртуальної STEM-лабораторії МАНЛаб Малої академії наук України. Зазначений ресурс пропонує дистанційну й очну фахову методичну та технологічну допомогу в організації STEMнавчання учнівської молоді України та спеціалізується на здійсненні досліджень у галузі природничих дисциплін: фізики, хімії, біології, географії, астрономії, екології, мінералогії. Освітнє середовище STEM-лабораторії охоплює навчальні програми, методичні матеріали, віртуальні лабораторії, які можуть бути корисними для учнів, студентів, учителів, науковців.

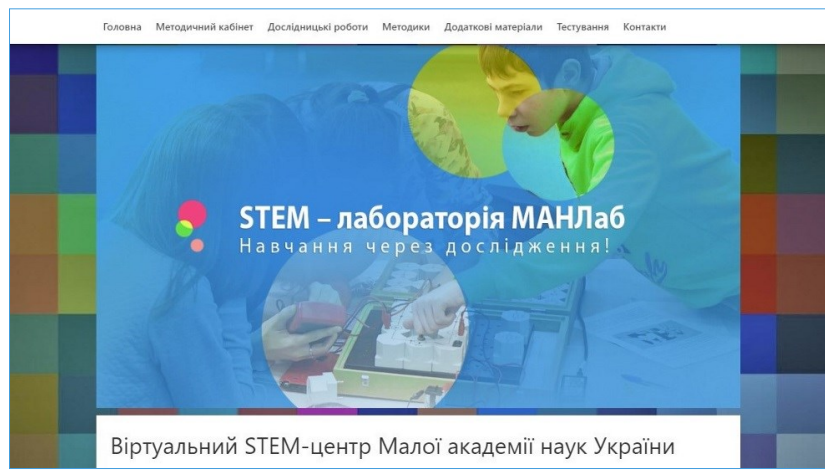

В умовах карантину значну частину запланованих заходів Інституту обдарованої дитини НАПН України було переведено в онлайн-режим 3 використанням програмних продуктів ZOOM, Skype, YouTube. Робота проводиться за окремими напрямами: розвиток здібностей дітей і молоді, надання психологічної та науково-методичної допомоги працівникам закладів освіти.

Для дітей 6-11 років розроблено освітньотворчий проєкт «Разом до прекрасного», автор Галина Кузьменко, кандидат педагогічних наук, старший науковий співробітник Інституту обдаро-

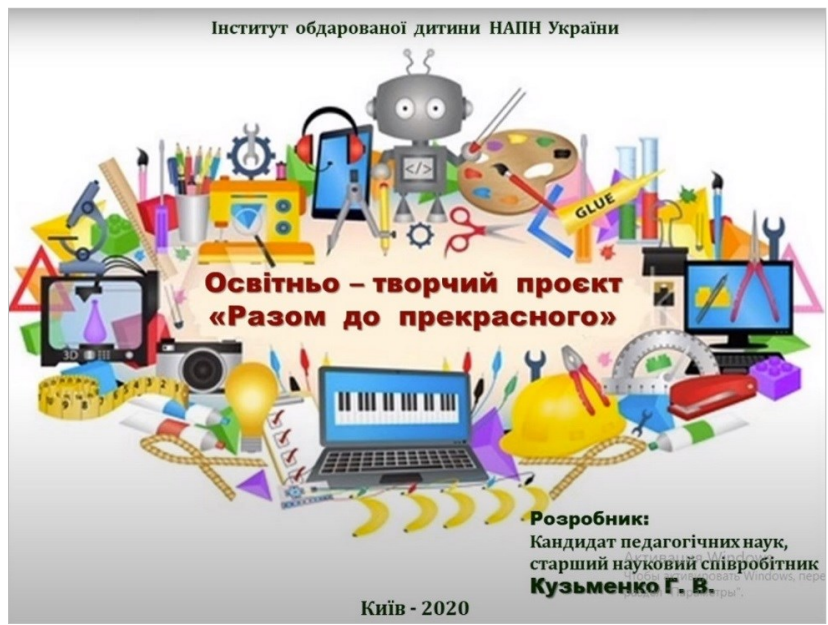


ваної дитини НАПН України, фахівець у галузі розвитку художньої творчості. У рамках освітньотворчого проєкту «Разом до прекрасного» успішно проведено перше онлайн-заняття: «Мистецтво графіки. Краса звичайної плями», трансляцію якого здійснено на каналі YouTube.

Для допомоги вчителям щодо особливостей організації ефективного онлайн-навчання проведено вебінар «Умови ефективного онлайннавчання та комунікації учнів під час карантину», кей-спікер вебінару - Наталія Панасенко, науковий співробітник Інституту обдарованої дитини НАПН України, методист Малої академії наук України. Під час цього заходу було здійснено аналіз онлайн-ресурсів, які можна застосовувати для дистанційного навчання, а вчителям запропоновано методики для утримання уваги дітей та алгоритми автоматизації навчального процесу. Проаналізовано труднощі, які можуть виникнути на етапі імплементації онлайн-навчання, запропоновано шляхи їх нівелювання.

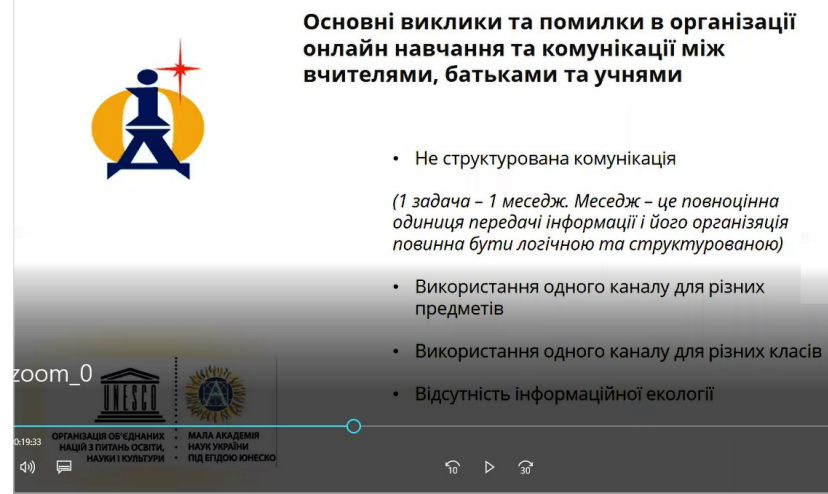

Усвідомлюємо, що сучасних учнів необхідно готувати до таких викликів та умов життя, які не відповідають сьогоденню. Перед педагогами та науковцями дедалі частіше постають проблемні питання. Чи можливо підготувати дитину до життя в майбутньому, якщо ми самі не дуже розуміємо яким це майбутнє буде? До чого саме потрібно готувати дітей, як їх варто навчати та виховувати? Чи є щось, що точно буде важливим та актуальним через 10-20-30 років? Як у школі навчити баченню і дії? Чи можна чекати в найближчому майбутньому істотного зміщення фокусу освіти з опанування soft skills на hard skills? Що таке «толерантність до невизначеності» та чому вона важлива? Чому педагогам варто турбуватися про себе та «бути у ресурсі»? Щоб дати відповіді на ці запитання, вчені Інституту обдарованої дитини НАПН України розпочали онлайн-проєкт «Навчання дітей майбутнього», автор - Марина Мельник, кандидат педагогіч них наук, завідувач відділу діагностики обдарованості Інституту обдарованої дитини НАПН України.

Було проведено перше онлайн-заняття, на якому вчителям запропоновано ознайомитися 3 новітніми тенденціями щодо наповнення змісту освіти, а також ключовими навичками майбутнього - soft skills i hard skills. Розкрито поняття «толерантність до невизначеності». Використано методики профілактики професійного стресу та «вигорання» для працівників закладів освіти.

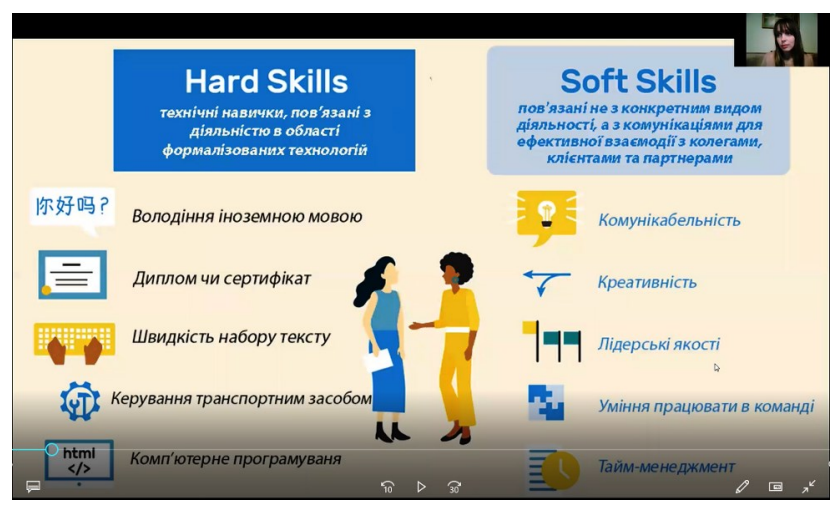

Це незначна частина роботи, яку наразі проводить Інститут обдарованої дитини НАПН України. Але вже сьогодні стає очевидно, що пандемія COVID-19 радикально видозмінює об'єктивну дійсність. Це закономірно приведе до трансформацій як наших уявлень про фундаментальні засади сучасної освіти, так і способів їі набуття.

\section{СПИСОК ВИКОРИСТАНИХ ДЖЕРЕЛ}

Віртуальна ТЕМ-лабораторія МАНЛаб. (n.d.) https://stemua.science/

Інститут обдарованої дитини НАПН України : офіційний вебсайт (n.d.). http://www.iod.gov.ua/

Кузьменко, Г.В. (2020, 9 квітня). Мистеитво графіки. Kраса звичайної плями : онлайн-заняття [Відео]. YouTube. https://youtu.be/ddHdqjzmGCO

Ocmpis знань : інтернет-портал. (n.d.). http:// ostriv.in.ua/

Портал тестування. (n.d.). https:// tests.pythonanywhere.com/ 


\section{ON THE DISTANCE MODE OF ACTIVITY OF THE INSTITUTE OF THE GIFTED CHILD OF THE NATIONAL ACADEMY OF EDUCATIONAL SCIENCES OF UKRAINE UNDER THE COVID-19 PANDEMIC}

Alona Malynoshevska

PhD in Pedagogy, Deputy Director for Scientific Work, Institute of the Gifted Child of the National Academy of Educational Sciences of Ukraine, Kyiv, Ukraine

Abstract. The article describes the main directions of online activity of the Institute of the Gifted Child of the National Academy of Educational Sciences of Ukraine under the quarantine, which was introduced in order to counteract the spread of COVID-19. It is noted that the Institute of the Gifted Child of NAES of Ukraine has considerable experience of remote communication and remote scientific and methodological support of the development of gifts and talents in children and young people. In particular, All-Ukrainian Educational Internet Portal "Knowledge Island", created by researchers of the Institute, has been functioning for many years. The materials of the portal are aimed at assisting the employees of educational institutions in the organization of distance learning, the development of cognitive interests of students, their intellectual and creative abilities. Researchers have developed an online resource for diagnosing students' abilities, professional interests, and aptitudes.

The COVID-19 pandemic has prompted an intensive search for new models of interaction within the framework of scientific and methodological support for the education of the gifted children. During the period of anti-epidemic measures initiated by the Government of Ukraine, the Institute's staff increased their presence on several digital platforms, providing online counselling for teachers on the problem of teaching the gifted students. Another area of research activity was holding webinars, withing which the latest trends in education of the gifted children are highlighted.

Keywords: Institute of the Gifted Child of NAES of Ukraine; All-Ukrainian Educational Internet Portal "Knowledge Island"; online resource for ability level diagnostics; educational and creative project; webinar.

Дата публікації: 30 квітня 2020 р. 